\title{
Biomass distribution of heterotrophic and autotrophic microorganisms of the photic layer in Cuban southern oceanic waters
}

\author{
Gladys Margarita Lugioyo ${ }^{1}$, Sandra Loza ${ }^{1} \&$ Paulo C. Abreu ${ }^{2}$ \\ 1 Institute of Oceanology, Ave 1ra No 18406 e/ 184 y 186, Reparto Flores, Playa, Ciudad de La Habana, Cuba; calva- \\ rez@infomed.sld.cu \\ 2 UFRG - Universidade Federal do Rio Grande, Cx.P. 474, Rio Grande/RS, CEP 96201-900, Brazil; docpca@super. \\ furg.br
}

Received 30-VI-2004. Corrected 18-IX-2006. Accepted 15-I-2007.

\begin{abstract}
We measured the vertical and seasonal distribution of picoplankton $(0.2-2 \mu \mathrm{m})$ and nanoplankton $(2-20 \mu \mathrm{m})$ in the photic layer of Cuban southern oceanic and coastal waters. The concentration of the different fractions was estimated by epifluorescence microscopy. Heterotrophic components from the different fractions showed higher vertical stratification in the oceanic station in comparison to the coastal one. The autotrophic components showed an irregular vertical distribution pattern, both in coastal and oceanic stations. In all the analyzed stations, the heterotrophic bacteria showed an inverse correlation with the autotrophic $(\mathrm{r}=-0.98)$, and the heterotrophic nanoplankton $(\mathrm{r}=-0.96)$. Auto and heterotrophic nanoplankton probably regulate bacteria abundance by predation, although autotrophic nanoplankton may represent a source of organic matter for microorganisms. Rev. Biol. Trop. 55 (2): 449-457. Epub 2007 June, 29.
\end{abstract}

Key words: Bacterioplankton, picoplankton, nanoplankton, vertical-seasonal distribution, oceanic waters, Cuba.

The quantitative significance of microbial heterotrophs in overall plankton metabolism and marine food web has received considerable attention over the past two decades (Hopkinson et al. 1989). Most of the autotrophic production processed by microorganisms would be oxidized within the microbial loop in the euphotic layer rather than being exported in the form of metabolic energy to higher-order consumers, or in the form of particle fall-out to deep waters (Legendre and Le Fèvre 1995).

The species diversity of picophytoplankton has not been completely characterized (Fenchel et al. 1997, Finlay et al. 1997). A further problem concerns the fraction of unknown species in picophytoplankton relative to those in other ecologically defined groups. Molecular genetic evidence (Pichard et al. 1997, Raven 1998) suggests that there is a considerable range of uncultured genotypes in cyanobacteria which are likely to be distinct at the species level at least, while such significant (in terms of number of individuals and of planktonic primary productivity deep in the euphotic zone) genera as Prochlorococcus have only been known for a relatively short time (Chisholm et al. 1988).

It is well known that bacteria are major components of marine ecosystems, often consuming up to half of the marine primary productivity by assimilation of dissolved organic matter and potentially transferring this material to protozoan grazers that also consume small algae (Ducklow 1986, Cho and Azam 1988). Autotrophic nanoplankton constitutes the primary producer of biomass in oligotrophic ecosystems and is the main component of living dissolved organic matter consumed by bacteria. On the other hand, bacterioplankton and heterotrophic nanoplankton are the main degraders 
and remineralizers of organic matter, being the bacterial and nanoplankton populations regulated by the grazing of microzooplankton (Putt et al. 1991, Potapova 1993). However, most of the collected data come from coastal systems and from the large oligotrophic ocean gyres, but deep-water information is scarce.

Assessment of the processes that take place in these waters is necessary for understanding the biological interactions on a global scale, as they make up a significant portion of the world ocean.

One of the first steps towards the understanding of how an ecosystem functions is to investigate the biomass distribution of the major involved organisms. Previous work has shown that in coastal surface waters, bacteria commonly represent from 5 to $20 \%$ of the microbial biomass, with phytoplankton usually making up the rest (Williams 1981). Although in summer, when dissolved nutrients are scarce, bacterial biomass sometimes exceeds that of phytoplankton (Boicourt et al. 1987).

The aim of this work was to determine the biomass and distribution of picoplankton and nanoplankton in Cuban southern oceanic waters, and their contribution to the biomass $<20 \mu \mathrm{m}$ in this ecosystem where the larval development of organisms of commercial interest, like fishes and crustaceans, takes place.

\section{MATERIALS AND METHODS}

The investigation was carried out in oceanic waters of the Exclusive Economic Zone (EEZ) south of Cuba that goes from Cape San Antonio to the surroundings of Santiago de Cuba Bay, and from the edge of the insular shelf to the legal limit of the EEZ (Fig. 1), with a depth varying between 1000 and 6000 m (Fernández et al. 1990). The photic layer extends to $200 \mathrm{~m}$, approximately, and the average annual surface temperature of the water is $26.4{ }^{\circ} \mathrm{C}$ (Victoria and Penié 1998).

Two stations were selected in the Exclusive Economic Zone south of Cuba. One in coastal waters, E.37 $\left(22^{\circ} 0.00^{\prime} \mathrm{N}\right.$ and $\left.80^{\circ} 5.00^{\prime} \mathrm{W}\right)$ with a depth of $900 \mathrm{~m}$, where surface temperature varied between $28.6^{\circ} \mathrm{C}$ and $29.5^{\circ} \mathrm{C}$ in summer, and between $25.9{ }^{\circ} \mathrm{C}$ and $26.3{ }^{\circ} \mathrm{C}$ in winter, and salinities ranged from $36.3 \%$ to $36.7 \%$ in the photic layer. The other one in oceanic waters, E. $88\left(20^{\circ} 2.06^{\prime} \mathrm{N}, 82^{\circ} 4.96^{\prime} \mathrm{W}\right)$ with a depth of $4900 \mathrm{~m}$, surface temperature varied between $28.3{ }^{\circ} \mathrm{C}$ and $29.5{ }^{\circ} \mathrm{C}$ in summer, and between $25.7{ }^{\circ} \mathrm{C}$ and $26.0{ }^{\circ} \mathrm{C}$ in winter, and salinities went from 36.2 to $36.6 \%$.

Water samples were taken at subsurface, 25, 75, 125 and $150 \mathrm{~m}$, using a 5 L Niskin bottle in July - August 1989 and January 1990. Sampling levels were selected taking into
E37

Biomass $\left(\mathrm{mgC} / \mathrm{m}^{3}\right)$

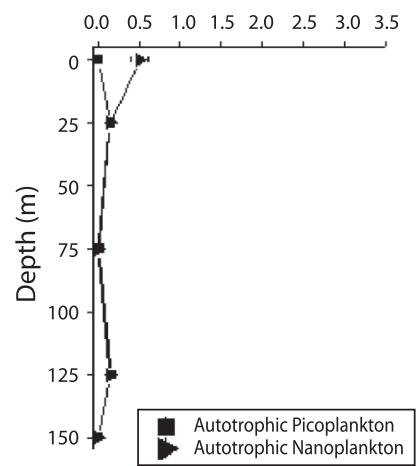

E88

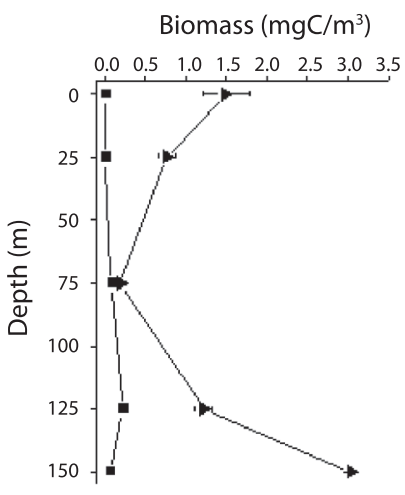

Fig. 1. Distribution of the autotrophic planktonic fractions $(<20 \mu \mathrm{m})$ with regard to depth (E.88) and at a coastal station (E.37) in winter. 
consideration the $1 \%$ irradiance, maximum of chlorophyll a, thermocline layer, and end of the photic layer. For biological analysis the water samples were taken in triplicate for each station. For determining the behavior of microorganisms during the day and at night, samples were collected at 10:00 $\mathrm{h}$ and 22:00 $\mathrm{h}$ at 0.25 and $125 \mathrm{~m}$ in depth, at the station E.88.

In each level, one liter of water was filtrated through a $20 \mu \mathrm{m}$ mesh using a vacuum pump for processing of picoplankton and nanoplankton. Differentiation of picoplankton $(0.2-2.0 \mu \mathrm{m})$ and nanoplankton $(2.0-20.0 \mu \mathrm{m})$ organisms was carried out by observation with an optical microscope (Liuman- II). Bacterial samples were preserved in $2 \%$ formaldehyde (final concentration), and phytoplanktonic ones in glutaraldehyde $(25 \%)$ and paraformaldehyde in order to obtain a final concentration of $1 \%$ (Tsuji and Yanagita 1981). Samples were stored in darkness at $-4{ }^{\circ} \mathrm{C}$ until analysis.

In order to separate heterotrophic bacteria from autotrophic picoplankton, different cellular dye techniques were used. Bacterial biomass was determined by counting total cells filtered through Nucleopore filters stained with acridine orange, using epifluorescence microscopy (Hobbie et al. 1977) with a Liuman- II microscope and magnification of $1000 \mathrm{X}$. In each sample no less than 300 cells were counted. The conversion factor to calculate the bacterial biomass was $1.4 \times 10^{-14} \mathrm{gCcell}^{-1}$ (Alongi 1988).

Picoplanktonic and nanoplanktonic biomass was determined by epifluorescence microscopy with primuline (Caron 1983). The samples were filtrated through acetate filters and mounted in slides; biomass was calculated using a conversion factor of $1000 \mu \mathrm{m}^{3} \mathrm{ml}^{-1}=$ $0.08 \mathrm{mgCm}^{-3}$ (Sherr and Sherr 1984).

Protein concentration was determined by a standard procedure (Lowry et al. 1951) and lipid concentration according to Agatova (1983). These parameters were used as indirect indicators of organic matter in the environment. Concentration of nitrates and nitrites and phosphate (soluble reactive phosphorus= SRP) were estimated according to Strickland and Parsons (1972), in the samples collected in triplicate at E.37 and E.88 stations as previously described.

In order to better understand the relationship between bacteria and nanoplankton, a correlation analysis was carried out using the statistical software MICROSTA version 3.1. Values in figures are shown as the mean value $(\mathrm{X}) \pm$ standard deviation (SD) $(\mathrm{n}=3)$.

\section{RESULTS}

In coastal waters (E.37), the autotrophic nanoplankton biomass ranged between 0 and 0.5 $\mathrm{mgCm}^{-3}$ with maxima at the surface layer and at a depth of $25 \mathrm{~m}$. Picoplankton showed similar vertical distribution, except at surface, with peak concentrations at 25 and $125 \mathrm{~m}$ (Fig. 1).

With regard to heterotrophic components, it was found that picoplankton, in special bacterial biomass, was the largest contributor to the total biomass $<20 \mu \mathrm{m}$ in the whole water column, with values ranging from 28.4 to 54.4 $\mathrm{mgCm}^{-3}$, the maximum values were found at 25 and $125 \mathrm{~m}$ depth, whereas the heterotrophic nanoplanktonic biomass was higher at surface and at $125 \mathrm{~m}$ (Fig. 2).

The oceanic station (E.88) showed higher values of autotrophic biomass when compared to station E.37. The nanoplankton biomass was the largest component among the autotrophic fractions studied, with maximum values at the surface $\left(1.5 \mathrm{mgCm}^{-3}\right)$ and at $150 \mathrm{~m}$ of depth (3.0 $\mathrm{mgCm}^{-3}$ ) (Fig. 1). On the other hand, for the heterotrophic fractions the bacterioplanktonic biomass in this station presented lower values (between 13 and $20 \mathrm{mgCm}^{-3}$ ) compared to those of the station E.37, with maximum values at $25 \mathrm{~m}$ of depth. Heterotrophic nanoplankton showed two maxima of biomass locations, one of them at $25 \mathrm{~m}$ deep and the other at 150 m (Fig. 2).

The coastal station (E.37) was characterized, in general, by the highest $\mathrm{PO}_{4}$, nitrates and nitrites concentrations, suspended protein and lipid concentrations when compared to E.88 (Table 1), thus showing the influence 
TABLE 1

Values ranges of some nutrients, suspending protein and lipids at the photic layer at E.37 and E.88 stations

\begin{tabular}{|c|c|c|c|c|c|}
\hline Stations & Range & $\mathrm{PO}_{4}(\mu \mathrm{M})$ & $\mathrm{NO}_{3}+\mathrm{NO}_{2}(\mu \mathrm{M})$ & $\begin{array}{l}\text { Suspending protein } \\
\qquad(\mu \mathrm{g} / \mathrm{mL})\end{array}$ & $\begin{array}{l}\text { Suspending lipids } \\
(\mu \mathrm{g} / \mathrm{mL})\end{array}$ \\
\hline & Min & 0.08 & 0.14 & 0.4 & 3.03 \\
\hline \multirow{3}{*}{ E.37 } & $\operatorname{Max}$ & 0.29 & 4.73 & 0.63 & 46 \\
\hline & $\mathrm{X}_{\text {mean }}$ & 0.15 & 2.6 & 0.53 & 21.3 \\
\hline & Min & 0.03 & 0.07 & 0.18 & 3.9 \\
\hline \multirow[t]{2}{*}{ E. 88} & $\operatorname{Max}$ & 0.29 & 6.03 & 0.8 & 14 \\
\hline & $\mathrm{X}_{\text {mean }}$ & 0.14 & 2.1 & 0.46 & 8.4 \\
\hline
\end{tabular}

E37

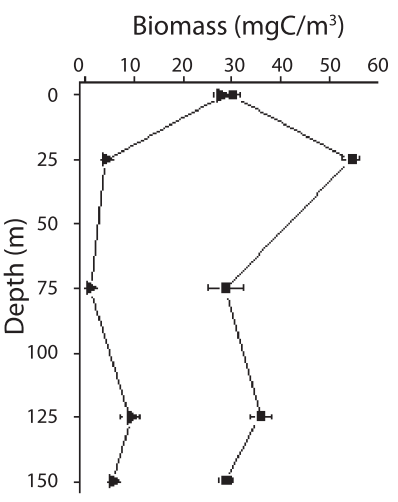

E88

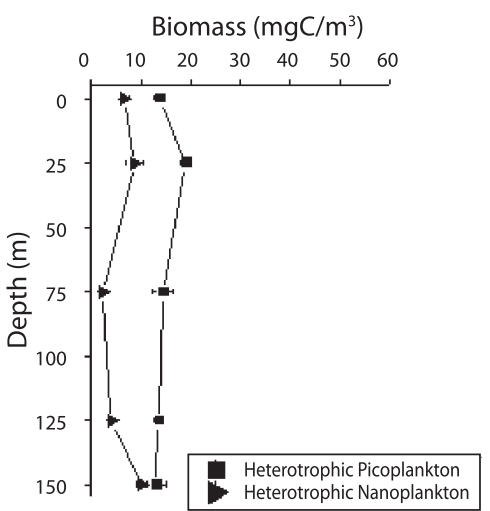

Fig. 2. Distribution of the heterotrophic planktonic fractions $(<20 \mu \mathrm{m})$ with regard to depth (E.88) and at a coastal station (E.37) in winter.

of coastal waters rich in organic matter and nutrients on the surrounding oceanic waters. It is important to notice that the highest nitrates and nitrites concentrations were found in January 1990 at the oceanic station (E.88). Other study, performed in the same period, found low chlorophyll $a$ concentrations in the coastal (E.37) (0.064-0.097 $\left.\mathrm{gg}^{-1}\right)$ as well as in the oceanic station (E.88) (0.058-0.064 $\left.\mu \mathrm{gl}^{-1}\right)$ (Melo et al. 1995).

At station E.37, as for the plankton distribution $(<20 \mu \mathrm{m})$ at the surface layer, there was a reduction in bacterial biomass in winter (January, 1990) when compared to summer (July-August, 1989) although the heterotrophic nanoplankton biomass increased (Fig. 3). On the other hand, in the oceanic station (E.88), both bacteria and heterotrophic nanoplankton had reduced biomass in winter, while autotrophic nanoplankton increased. Thus, in general, bacterial biomass in winter decreases 3.5 times regarding the values obtained in summer; the autotrophic nanoplankton increases five times in winter; whilst the heterotrophic nanoplankton showed different patterns in each station.

The vertical distribution of the fractions studied during a daily cycle showed that total picoplanktonic biomass, whose most abundant component are bacteria, was the one which contributed mostly to the total biomass 


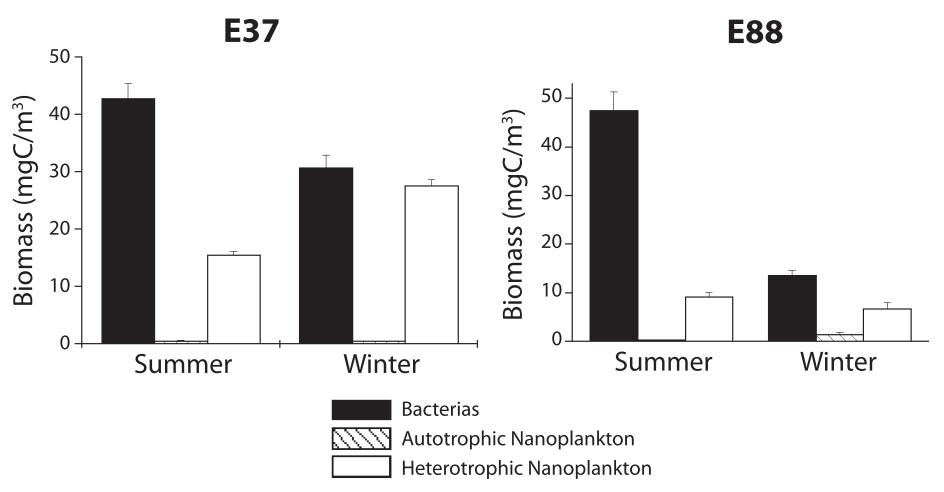

Fig. 3. Behavior of planktonic fractions $(<20 \mu \mathrm{m})$ in summer (July 1989) and winter (January 1990) in one station with coastal influence and one oceanic station.

(>60\%), in both periods, i.e., night and day, showing an homogeneous pattern, in the water column (Fig. 4). Total nanoplankton was the second fraction producing the next highest contribution of $26.9 \%$, (the highest values were at the water surface). Highest biomass values were obtained during the day.

The heterotrophic bacteria showed inverse relationships with the autotrophic nanoplankton $(\mathrm{r}=-0.88, \mathrm{p}<0.05)$, and with the heterotrophic nanoplankton $(\mathrm{r}=-0.96, \mathrm{p}<0.05)$, in all the stations studied.

\section{DISCUSSION}

Total autotrophic biomass was extremely low at both stations, indicated by cellular counts, and biovolume measurements, as well as chlorophyll a concentrations (Melo et al. 1995). Our results show that Cuban oceanic waters are poor. Small autotrophic biomass is a common feature of the Caribbean region, as demonstrated by measurements of chlorophyll $a$ concentrations, in summer $\left(0.07 \mathrm{mgm}^{-3}\right)$ and winter $\left(0.13 \mathrm{mgm}^{-3}\right)$, near the Cuban Island (Melo et al. 1995). These authors have also reported that photosynthetic pigment concentrations in Sargasso Sea $\left(0.05-0.08 \mathrm{mgm}^{-3}\right)$ and Gulf of Mexico (0.06-0.30 $\mathrm{mgm}^{-3}$ ) were low.

In general, primary production in oligotrophic regions, as well as in Cuban oceanic waters, is mainly sustained by picoplankton $(0.2-2.0 \mu \mathrm{m})$ and, in some cases, nanoplankton $(2-20 \mu \mathrm{m})$ (Ning et al. 1993, Magazzu and Decembrini 1995). Transference of matter and

\section{E88}

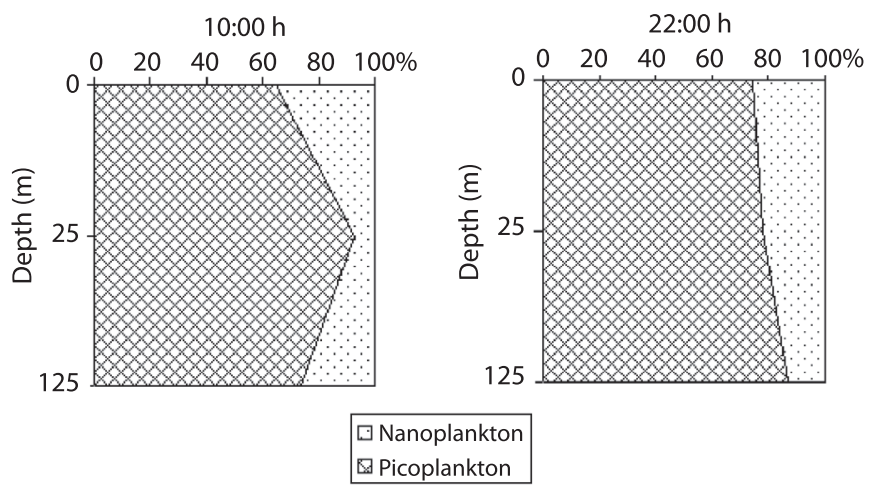

Fig. 4. Relative contribution of planktonic fractions $(<20 \mu \mathrm{m})$ to total biomass with regard to depth daily cycle in the oceanic station (E.88) in July 1989. 
energy from primary producers to top predators occurs through several levels, leading to a long and not so efficient food web (Stoecker et al. 1994, Pinet 1998, Sherr and Sherr 2000).

Cuban oligotrophic waters are characterized by the dominance of small cells, according to this study. The high surface/volume cell ratios make these organisms more efficient in the competition for dissolved inorganic nutrients and light, especially in environments where nutrients are present in low concentration (Raven 1998). The relative high values of autotrophic nanoplankton observed at the surface and at $125 \mathrm{~m}$ deep of the oceanic station (E.88) in comparison to the coastal station (E.37) is surprising, since coastal regions usually have higher nutrient input. However, since the phytoplankton of Southern Cuban coastal region is dominated by diatoms and dinoflagellates (Loza et al. 1994), it is possible that a larger fraction of primary producers at E.37 station could be made up of microphytoplankton organisms $(20-200 \mu \mathrm{m})$, not determined in this study. High autotrophic biomass found at the E.88 station, probably resulted from the input of enriched deep waters of neighboring shelves (Fernández et al. 1990). Besides, this fraction is generally found at the pycnocline (125-150 m) of oligotrophic waters, as a result of phytoplankton chromatic adaptations to low light conditions (Sorokin and Mamaeva 1980, Richardson et al. 1983, Li and Wood,1988). Anyhow, the higher autotrophic nanoplankton biomass measured at the oceanic station suggests the importance of these photosynthesizing organisms to the production of organic matter and the recycling of nutrients of the southern Exclusive Economic Zone of Cuba.

It is noteworthy, however, that heterotrophic biomass (mainly bacteria) surpassed several times the biomass of autotrophic organisms, being the largest contributor to the total biomass $<20 \mu \mathrm{m}$ in the photic layer of both stations in Southern Cuban oceanic waters. This indicates that bacteria are an important link in the transfer of organic matter to higher trophic levels of this aquatic ecosystem, which is based on the fact that chlorophyll $a$ concentrations reported by Melo et al. (1995) in the same area were low $\left(0.07-0.13 \mathrm{mgCm}^{-3}\right)$. Similar results were reported by Caron et al. (1995) in the Sargasso Sea, where they found that bacterioplankton represents a significant fraction of the total particulate Carbon and Nitrogen and the nanoplankton was the second high contributor to biomass $<20 \mu \mathrm{m}$ in this ecosystem.

Although the coastal and oceanic stations analyzed in this study showed very similar patterns, it seems that waters around Cuba show different patterns of plankton size structure. Lugioyo et al. (2005), when analyzing the contribution of planktonic biomass $<200$ $\mu \mathrm{m}$ in the photic layer in oceanic waters around Cuba, found that in the southern EEZ the microzooplanktonic fraction contributes the least (30\%). However, a similar study conducted in northern Cuba showed that nanoplankton constitutes the largest fraction $(44.5 \%)$ of biomass $<200 \mu \mathrm{m}$ followed by microzooplankton $(33.2 \%)$, while bacteria contribute only $22.3 \%$ (Lugioyo et al. 1999).

In most aquatic environments, bacteria are sustained by the dissolved organic carbon produced by phytoplankton (Fuhrman et al. 1989, Casotti et al. 2000). Yet, according to our results, the biomass of autotrophic components was low and is not likely to be the support of bacteria and the heterotrophic nanoplankton biomass observed.

Possible explanations to this discrepancy could be that picoplankton and nanoplankton of both stations would have higher metabolic efficiency, producing large quantities of organic matter with low biomass, or that phytoplankton cells could be under extreme grazing pressure in these ecosystems. In this case, bacteria would benefit from the dissolved organic Carbon released by phytoplankton when these are consumed by grazers ("sloppy feeding") (Nagata 2000).

In any case, in a complex ecosystem such as oligotrophic oceanic waters, more than one of the above-mentioned explanations could be valid; in summary, the joint effect of several processes could support the production of heterotrophic biomass from bacteria and nanoplankton. 
Regarding short-term temporal variation, no significant differences were observed between day and night for bacterial biomass, differently from other planktonic components. This could be explained by the short doubling times of bacteria. Differences in the longterm study were more conspicuous after the analysis of winter and summer data. Higher temperatures in summer at station E.88 could have stimulated the development of the bacterial community in oceanic waters. Pomeroy and Wiebe (2001) showed that temperature and organic substrates are the limiting factors for growth of marine bacterial community in an oligotrophic environment.

On the other hand, it seems that the vertical mixing of the water column in winter has influence on the autotrophic nanoplankton, which was favored by nutrients from deep layers. However, the effect of both factors was not evident in the heterotrophic nanoplankton response.

On the contrary, in the coastal station (E.37) no differences were observed between summer and winter for the planktonic distribution $(<20 \mu \mathrm{m})$. It was suggested that the dynamics of this station is largely controlled by nutrient and organic matter inputs from the Gulf of Batabanó (SW, Cuba), Gulf of Ana María (SE, Cuba), and Cienfuegos Bay, at any time of the year (Fernández et al. 1990).

In the oceanic station (E.88), the nanoplanktonic fraction, during the day, seems to exert control over the picoplanktonic population, particularly in surface and 125 m layers. However, at night, the nanoplankton biomass diminishes. It could be related to the grazing pressure exerted by the zooplankton that reduces its grazer effect upon the picoplanktonic fraction (Fig. 3). The negative correlations between bacteria and autotrophic and heterotrophic nanoplankton obtained in this work can be interpreted as grazing pressure of these organisms on bacteria.

Several studies show that many autotrophic organisms may consume bacteria if nutrients are present at low levels (Mixotrophy) (Caron 2000). The ingestion of bacteria by mixotrophic organisms may represent an important path of
Carbon transference to other trophic levels (Caron 2000). Moreover, although autotrophic nanoplankton represents an important organic substrate to bacteria, the negative correlation can also indicate the success of bacteria in the competition of both groups for dissolved inorganic nutrient.

It is still matter of debate in which extent availability of carbon sources or predation have a higher relevance on bacterial community regulation (Thingstad 2000). This is an extremely complex phenomenon and all evidence indicates that combination of both, nutrient limitation and predation, are the most important determinants for the bacterial community structure (Matz and Jürgens 2003).

The results of this study showed the importance of the smaller planktonic fractions at the microbial food web of coastal and oceanic waters in the South of Cuba. Further studies of processes like primary and secondary production, respiration and grazing should be conducted in order to determine the levels of transference of matter and energy in this ecosystem.

\section{ACKNOWLEDGMENT}

This research was supported by the Institute of Oceanology Institute of Cuba, G.M Lugioyo had financial support from The Third World Academy of Sciences (TWAS), and a grant from CNPq (Proc. No. 170365/01-8).

\section{RESUMEN}

Determinamos la distribución vertical y estacional del picoplancton $(0.2-2 \mu \mathrm{m})$ y el nanoplancton $(2-20 \mu \mathrm{m})$ en la capa fótica de las aguas oceánicas y costeras al sur de Cuba. La concentración de las diferentes fracciones fue estimada mediante microscopía de epifluorescencia. Los componentes heterotróficos de las diferentes fracciones mostraron una elevada estratificación vertical en la estación oceánica en comparación con la estación costera. Por otro lado, los componentes autotróficos presentaron un patrón de distribución vertical irregular tanto en la estación costera como en la oceánica. En los análisis realizados las bacterias heterótrofas mostraron una correlación inversa con el nanoplancton autótrofo $(r=-0.98)$, y con 
el nanoplancton heterótrofo $(\mathrm{r}=-0.96)$. Estos resultados sugieren que el nanoplancton (autótrofo y heterótrofo) probablemente regula la abundancia de bacterias mediante la depredación, además que el nanoplancton autótrofo pudiera representar una fuente de materia orgánica para los microorganismos.

Palabras clave: bacterioplancton, picoplancton, nanoplancton, distribución vertical y estacional, aguas oceánicas, Cuba.

\section{REFERENCES}

Agatova, A.I. 1983. Recomendaciones para la determinación de materia orgánica en el mar. Onit Vniro. Nauka, Moscow, Russia. 45 p.

Alongi, D. 1988. Bacterial productivity and microbial biomass in Tropical mangrove sediments._Microb. Ecol. 15: 59-79.

Boicourt, W.C., S.Y. Chao, T.C. Ducklow, M.R. Roman, L.P. Sanford, J.A. Fuhrman, C. Garside \& R.W. Garvine. 1987. Physics and microbial ecology of a buoyant estuarine plume on the continental shelf. EOS Trans. Am. Geophys. Un. 68: 666-668.

Caron, D.A. 1983. Technique for enumeration of heterotrophic and phototrophic nanoplankton, using epifluorescence microscopy, and comparison with other procedures. Appl. Environ. Microbiol. 46: 491-498.

Caron, D.A. 2000. Simbiosis and mixotrophy among pelagic microorganisms, p. 495-523. In D.L. Kirchman (ed.). Microbial Ecology of the Oceans. Wiley, New York, USA.

Caron, D.A., A.F. Michaels, N.R. Swanberg \& F.A. Howse. 1995. Primary productivity by symbiont-bearing planktonic sarcodines (Acantharia, Radiolaria and Foraminifera) in surface waters near Bermuda. J. Plankton. Res. 17: 103-129.

Casotti, R., C. Brunet, B. Aronne \& M. Ribera d'Alcala. 2000. Mesoscale features of phytoplankton and planktonic bacteria in a coastal area as induced by external water masses. MEPS 195: 15-27.

Chisholm, S.W., R.J. Olson, E.R. Zettler, R. Goericke, J.B Waterbury \& N.A. Welshmeyer. 1988. A novel freeliving prochlorophyte abundant in oceanic euphotic zone. Nature 334: 340-343.

Cho, B.C. \& F. Azam. 1988. Major role of bacteria in biogeochemical fluxes in the ocean's interior. Nature 332: 441-443.
Fenchel, T., G.F. Esteban \& P.J. Finlay. 1997. Local versus global diversity of microorganisms: cryptic diversity of ciliate protozoa. Oikos 80: 220-225.

Fernandez, M., R.M. Hidalgo, D. López, I. García \& I. Penié. 1990. Caracterización hidroquímica en la Fosa de Jagua y la ZEE al S de Cuba. In Inf. Final Tema. Arch. Cient. Inst. Oceanol., La Habana, Cuba. 25 p.

Finlay, B.J., S.C. Maberly \& J.I. Cooper. 1997. Microbial diversity and ecosystems function. Oikos 80: 209-213.

Fuhrman, J.A., T.D. Sleeter, C.A. Carlson \& L.M. Proctor. 1989. Dominance of bacterial biomass in the Sargasso Sea and its ecological implications. Mar. Ecol. Prog. Ser. 57: 207-217.

Hobbie, J.E., R.J. Daley \& S. Jasper. 1977. Use of Nucleopore filters for counting bacteria by fluorescence microscopy. Appl. Environ. Microbiol. 33: $1225-1228$

Hopkinson, C.S., B. Sherr \& W. Wiebe. 1989. Size fractionated metabolism of coastal microbial plankton. Mar. Ecol. Prog. Ser. 51: 155-166.

Legendre, L. \& J. Le Fèvre. 1995. Microbial food webs and the export of biogenic carbon in oceans. Aquat. Microb. Ecol. 9: 69-75.

Li, W.K. \& A.M. Wood. 1988. Vertical distribution of North Atlantic ultraphytoplankton: analysis by flow cytometry and epifluorescence microscopy. Deep. Sea. Res. 35: 1615-1638.

Lowry, O.H, N.J. Rosenbrough, A.L. Farr \& R.J. Randall. 1951. Protein measurement with the folin phenol reagent. J. Biol. Chem. 193: 265.

Loza, S., R. Pérez \& C. Gil. 1994. Spatial and temporal variability and photosynthetic pigments the phytoplankton population in the South oceanic waters of Cuba. Proc. Int. Round Table Carib. Sea SOS, La Habana, Cuba. 64 p.

Lugioyo, M., S. Loza \& M.V. Orozco. 1999. Distribución espacial del plancton $(<200 \mu \mathrm{m})$ en las aguas oceánicas al norte de Cuba. Rev. Biol. Trop. 47: 65-70.

Lugioyo, G.M., S. Loza \& M.V. Orozco. 2005. Distribución vertical de las fracciones planctónicas y su contribución a la biomasa $<200 \mu \mathrm{m}$ en las aguas oceánicas adyacentes a Cuba. Rev. Inv. Mar. 26: 149-158.

Maggazzu, G. \& F. Decembrini. 1995. Primary production, biomass and abundance of phototrophic picoplankton in the Mediterranean Sea: A review. Aquat. Microb. Ecol. 9: 97-104. 
Matz, C. \& K. Jürgens. 2003. Interaction of nutrient limitation and protozoan grazing determines the phenotypic structure of a bacterial community. Microb. Ecol. 45: 384-398.

Melo, N., R. Pérez \& S. Cerdeira. 1995. Variación espaciotemporal de los pigmentos del fitoplancton en zonas del Gran Caribe, a partir de imágenes del satélite Nimbues 7 (CZCS). Avicennia 3: 103-116.

Nagata, T. 2000. Production mechanisms of dissolved organic matter, p. 121-152. In D.L. Kirchman (ed.). Microbial Ecology of the Oceans. Wiley, New York, USA.

Ning, X., Z. Lin \& J. Shi. 1993. Standing crop and productivity of phytoplankton and POC in Prydz Bay and adjacent waters. Antarct. Res. Nanji. Yanjiu. 5: $50-62$

Pichard, S.L., L. Campbell \& J.H. Paul. 1997. Diversity of the ribulose bisphosphate carboxylase/oxygenase Form I gene $(\mathrm{rbcl})$ in natural phytoplankton communities. Appl. Environ. Microbiol. 63: 3600-3606.

Pinet, P.R. 1998. The properties of seawater Chapter 4, p. 118165. In P.R. Pinet (ed.). Invitation to Oceanography. Jones and Barthett, London, England. 439 p.

Pomeroy, L.R. \& W.J. Weibe. 2001. Temperature and substrates as interactive limiting factors for marine heterotrophic bacteria. Aquat. Microb. Ecol. 23: 187-204.

Potapova, N.A. 1993. Destruction of organic matter in different size fractions of plankton in lower Dniester and Deniester liman. Gidrobiol Zh. Hydrobiol. J. 29: $12-22$.

Putt, M., D. Stockner \& J. Altstatt. 1991. Bacterivory in Mc Murdo Sound: 1.Grazing by heterotrophic nanoflagellates. Antarct J. U.S. 26:139-140.

Raven, J.A. 1998. The twelfth Tansley Lecture, small is Beautiful: The Picoplankton. Funct. Ecol. 12: 503-513.
Richardson, K., J. Beardall \& J.A. Raven. 1983. Adaptation of unicellular algae to irradiance: an analysis of strategies. New Phytologist. 93: 157-191.

Sherr, B. \& E. Sherr. 1984. Epifluorescence method for enumerating aquatic protozoa. Appl. Environ. Microb. 46: 1388-1393.

Sherr, E. \& B. Sherr. 2000. Marine microbes: an overview, p. 13-46. In D.L. Kirchman (ed.). Microbial Ecology of the Oceans. Wiley, New York, USA.

Sorokin, Yu.I. \& T.I. Mamaeva. 1980. Bacterial Production and Degradation of Organic Matter in Pacific Waters off Peru. Nauka, Moscow, Russia. 137 p.

Stoecker, D.K., M.E. Sieracki, P.G. Verity, A.E. Michaels, E. Haugen, P.H. Burkill \& E. Eduards. 1994. Nanoplankton and protozooan microzooplankton during the J60FS North Atlantic bloom experiment: 1989 and 1990. J. Mar. Biol. Ass. U.K. 74: 427-443.

Strickland, J.D. \& T.R. Parsons. 1972. A Practical Handbook of Seawater Analysis. Fish. Res. Board, Ottawa, Canada. 310 p.

Thingstad, T.F. 2000. Control of bacterial growth in idealized food webs, p. 229-260. In D.L. Kirchman (ed.). Microbial Ecology of the Oceans. Wiley, New York, USA.

Tsuji, T. \& T. Yanagita 1981. Improved fluorescent microscopy for measuring the standing stock of phytoplankton including fragile components. Mar. Biol. 64: $207-211$

Victoria del Rio, I. \& I. Penie. 1998. Hidrología, p.117-125. In M. Vales, A. Álvarez, L. Montes \& A. Ávila (eds.). Estudio Nacional sobre la Diversidad Biológica en la República de Cuba. UMA/CENBIO/ IES/ AMA /CITMA, Habana, Cuba.

Williams, P.J. 1981. Microbial contribution to overall marine plankton metabolism: direct measurements of respiration. Oceanol. Acta 4: 359-364. 
